\title{
Information technology in financial sector Russian Federation - driver of the formation of the Russian economy
}

\author{
Yulia Evdokimova ${ }^{1, *}$, Elena Egorova $^{1}$, and Olga Shinkareva ${ }^{2}$ \\ ${ }^{1}$ Russian State Social University, Wilhelm Pic Str., b. 4 ap.1, 129226 Moscow, Russia \\ ${ }^{2}$ Moscow City University, Selskokhozyaystvenny Drive 58, b. 4 ap. 1, 2, 129226 Moscow, Russia
}

\begin{abstract}
The digital changes taking place in all areas of society are most evident in certain sectors, especially in financial sector. One of the drivers of the modern development of a sustainable economy is the digitalization of society associated with the rapid development of information technologies. Informatization of this sector in Russia is associated with the synthesis of changes in the legal, economic, social, political nature. The article is devoted to key trends in the informatization of the financial sector of Russia. Analysis of the main suppliers of information technologies in the financial sphere and their products was made. Priority directions of development of information technologies in the financial sector and ways of their implementation are identified. The main approaches to strengthening information security and reliability of financial technologies in Russia have been studied. Synthesis of materials on information technologies researches in the financial sector of Russia was carried out.
\end{abstract}

\section{Introduction}

Digital transformation of any sector of economy is formed on the basis of such components as state policy, information technologies and business processes. At the same time, creative competition comes to the fore [1]. These components can ensure sustainable development and increase the potential of the economy to meet the needs of society.

The digital transformation of the financial sector increases the quality and speed of interaction between consumers of financial services and financial organizations, but at the same time creates additional risks. Digital channels are becoming the main competitive advantage [2].

The landscape of information banking security is constantly changing, which gives rise to new forms of circumvention of security measures. Factors affecting banking security include political, social, technological and legislative components [3]. This relationship demonstrates the need to address these aspects together, given the importance of each in achieving the planned outcome.

\footnotetext{
*Corresponding author: EvdokimovaIuV@rgsu.net
} 


\section{Materials and Methods}

The object of this study is the financial sector of the Russian Federation. The subject of the study are processes in Russian financial sector as a result of its digital transformation. These processes are associated with the strengthening of the information component, an increase in the risks of cyber-attacks and the growth of cybercrime in this sector. The main goal of this study is to identify key trends in the development of information technologies in the financial sector of the Russian Federation. The aim of the study is also to consider ways to optimize the existing and projected risks of the financial sector by analyzing the existing information technologies and strengthening its information security

Analysis, synthesis, induction, deduction was used as research methods. The main distinguishing feature of this study is its multidisciplinary nature, there is a clear interconnection of sectors such as information technology, financial technologies, economic aspects.

\section{Results and Discussion}

It must be borne in mind that almost a fifth part of all cyber attacks in the world (17\%) are in the financial sector. The United States of America, Canada, Singapore, Australia, Malaysia, New Zealand, Japan, Great Britain, Austria are most attractive to the financial sector today, so they have greater protection against cybercriminals than other countries. The main risks in the financial and credit sector associated with the informatization of this sector include:

- financial losses of financial services consumers caused by the growth of cybercrime;

- financial losses from cybercrime of some financial and credit institutions critical to their financial situation;

- decrease of operational reliability and impossibility of continuity of financial services provision to clients, which leads to decrease of reputation and increase of social tension in society;

- the possibility of a systemic crisis in the presence of serious information security problems due to cyber-attacks in banks significant for the national market.

The current development of information security and information technologies in the credit and financial sphere of the Russian Federation is based on the experience of the US National Institute of Standards and Technology, the Monetary Authority of Singapore, the Committee on Payment and Market Infrastructures at the Bank for International Settlements, the Basel Committee on Banking Supervision and other important organizations [4].

Priority areas for information technology development in the financial sector should be highlighted. These are big data management, artificial intelligence-based technologies, financial sector robotization, digital customer service channels, the formation of a deployed cyber threat protection system, Open source platforms, Web solutions that optimize the bank's internal processes, outstaffing, and banking insights. These technologies provide for a new format of financial business, qualitatively different business models, as well as a serious change in the national regulator information technologies [5].

The use of artificial intelligence in the banking sector is quite active. The rating agency Expert RA and RAEX (RAEX-Analytics) presented the classification of Russian banks on their use of information technologies based on artificial intelligence. The results are shown in Table 1. 
Table 1. Classification of Russian banks by level of technology use based on artificial intelligence [6]

\begin{tabular}{|c|c|}
\hline Level & Banks \\
\hline Significantly higher than average & Tinkoff Bank, Gazprombank, MTS Bank \\
\hline Above Average & $\begin{array}{c}\text { Moscow Credit Bank, Russian Standard Bank, } \\
\text { Promsvyazbank, Renaissance Credit Bank }\end{array}$ \\
\hline Close enough to average & $\begin{array}{c}\text { Ural bank of reconstruction and development, BKS Bank, } \\
\text { DeltaCredit Bank, Otkritie Bank }\end{array}$ \\
\hline
\end{tabular}

The study covered 50 banks from among the top 100 in assets. The final assessment sums up two factors: the use of artificial intelligence as part of credit analysis and the use of artificial intelligence as part of the bank's activities as a whole. The first factor is given a share of $45 \%$, the second factor $-55 \%$.

The informatization of Russian financial sector is at a fairly high level. The leaders of informatization in all activity areas are the largest banks. Other banks focus on front office and client back office digital technologies. The most important projects in the field of informatization of Russian financial sector are associated with the introduction of state initiatives in this direction, projects of Bank of Russia. This is the Unified biometric system, Faster payment system, creation of a marketplace [7].

The coronavirus pandemic has revealed new financial sector challenges and opportunities. The transition to remote service has shown the need and attractiveness of many digital services [8]. The Markswebb Internet Banking Rank 2020 provided for the formation of final values based on the fulfillment of day-to-day tasks that were set for banks in the pandemic. These values are shown in Table 2.

Table 2. Day-to-day tasks implemented by Internet banks and their share [9]

\begin{tabular}{|l|c|}
\hline \multicolumn{1}{|c|}{ Day-to-day task } & Share, $\%$ \\
\hline Convenience assessment & 15 \\
\hline Money transfer within Russia or abroad & 12 \\
\hline Making payments & 12 \\
\hline Check product status & 12 \\
\hline Receiving cash flow information & 9 \\
\hline Control and payment of invoices, fines and taxes & 6 \\
\hline Automate and simplify operations & 6 \\
\hline Repayment of loan arrears & 4 \\
\hline Getting a translation & 4 \\
\hline Online Bank login & 4 \\
\hline Control of bank commissions & 3 \\
\hline Managing funds in accounts & 3 \\
\hline Convenience of payments and transfers & 3 \\
\hline Debit card management & 3 \\
\hline Support for complex tasks & 2 \\
\hline Export data from an online bank & 2 \\
\hline
\end{tabular}

According to the results of the rating, were allocated banks the most clearly adapted to consumer requests in the conditions of priority of remote banking (the first ten positions). The data are shown in Table 3. 
Table 3. Rating of Internet banks for individuals [9]

\begin{tabular}{|c|c|c|}
\hline Position, year 2020 & Bank & Rating \\
\hline 1 & Tinkoff Bank & 68,0 \\
\hline 2 & Otkritie Bank & 67,3 \\
\hline 3 & Ak Bars Bank & 61,1 \\
\hline 4 & Bank Levoberezhny & 60,9 \\
\hline 5 & VTB & 57,9 \\
\hline 6 & Post Bank & 56,5 \\
\hline 7 & Promsvyazbank & 54,2 \\
\hline 8 & Raiffeisenbank & 53,4 \\
\hline 9 & Russian Agricultural Bank & 53,0 \\
\hline 10 & SKB-Bank & 52,9 \\
\hline
\end{tabular}

Innovative changes in the financial sector associated with digital transformation require significant investment. The total revenue of the largest suppliers of information products and technologies for the banking sector in 2018 increased by $8.9 \%$ compared to 2017 . Detailed information on suppliers (five leaders) is provided in table 4.

Table 4. Revenue of leading information technology suppliers for banks in Russia in 2017-2018 [5]

\begin{tabular}{|c|c|c|}
\hline Organization & $\begin{array}{c}\text { Revenue from projects } \\
\text { for banks in the field of } \\
\text { information technology, } \\
\text { million rubles }\end{array}$ & $\begin{array}{c}\text { Changes, 2018- } \\
\mathbf{2 0 1 7} \boldsymbol{\%}\end{array}$ \\
\hline Center of Financial Technologies & 22600 & $+10,2$ \\
\hline Sbertech & 20533 & $-32,3$ \\
\hline Softline & 18250 & +34 \\
\hline ITG & 13009 & $+3,1$ \\
\hline Jet & 12323 & $+21,7$ \\
\hline
\end{tabular}

Let's look at the most important products and technologies sold by leading information technology providers - Center of Financial Technologies and Sberteh. They are shown in Table 5.

Table 5. Information technologies and products sold by information technology suppliers to banks in the Russian Federation [5]

\begin{tabular}{|c|c|c|c|}
\hline Organization & $\begin{array}{l}\text { Information } \\
\text { technologies }\end{array}$ & Products & Banks \\
\hline $\begin{array}{c}\text { Center of } \\
\text { Financial } \\
\text { Technologies }\end{array}$ & $\begin{array}{c}\text { Faster payment } \\
\text { system, Remote } \\
\text { banking systems, } \\
\text { SaaS - Software as a } \\
\text { service, Automated } \\
\text { banking systems }\end{array}$ & $\begin{array}{c}\text { Bank Self-Service Platform, } \\
\text { Faktura.ru }\end{array}$ & $\begin{array}{c}\text { Sarovbusinessbank, } \\
\text { Alexandrovsky Bank, } \\
\text { Kremlin Bank, } \\
\text { Tomskpromstroybank, } \\
\text { Gaztransbank and } \\
\text { others }\end{array}$ \\
\hline Sbertech & $\begin{array}{c}\text { IT outsourcing, } \\
\text { Database } \\
\text { management system, } \\
\text { Network application } \\
\text { performance } \\
\text { management systems, } \\
\text { Data center - data } \\
\text { center technologies, } \\
\text { server platforms }\end{array}$ & $\begin{array}{l}\text { Projects on the basis of } \\
\text { blockchain technology, Qlik } \\
\text { Sense, MongoDB the } \\
\text { Database of NoSQL-type, } \\
\text { Apache Cassandra, GridGain } \\
\text { In-Memory Data Fabric, } \\
\text { Projects of creation of } \\
\text { complex IT infrastructure }\end{array}$ & Sberbank \\
\hline
\end{tabular}


The main approaches to enhancing information security and the reliability of financial technologies include the following four components:

- legal regulation established by federal laws,

- creation and development of a secure and cyber-resistant financial infrastructure that includes remote identification platforms; marketplace; Faster payment system, a platform for recording financial transactions; Bank of Russia payment system; the national payment card system Mir; a financial messaging system; Cloud services platform distributed registry technology platform,

- application of the latest developments such as financial technologies RegTech (regulatory technology), SupTech (supervision technology); Big Data, Smart Data; development of mobile technologies; development of technologies based on artificial intelligence, application of developments in the field of robotics and machine training; active biometrics developments; Introduction of distributed registry technologies; active use of open interfaces,

- examination of innovative financial technologies, products and services within the regulatory platform of the Bank of Russia taking into account possible cyber risks, modelling of possible threats and ways to minimize them [10].

The change in approaches to banking security in the information sphere is dictated by the predominance of mobile technologies for conducting financial transactions and a decrease in the use of desktop computers. Telephone banking is also losing its position. These changes are related to the preferences of millennials and Generation Z.

The growth of consumer preference for mobile devices causes an increase in the number of vulnerabilities, threats and risks. All these positions are prerequisites that security must be laid down from the very beginning, and not record the facts of cybercrime that have already been committed. Often fraudulent processes are subject to registration and activation of a mobile device when forming an online account or conducting a transaction. The development of bank applications directly affects the reputation of the brand, which requires constant strengthening of their security.

Open banking also has a number of serious vulnerabilities, the main of which is the risk of data leakage, despite clear legislative support in a number of countries. It should also be noted that the presence of weak vulnerabilities in the information infrastructure of third-party suppliers will cause an increase in fraudulent payments next year.

Artificial intelligence is increasingly being used by the financial sector - its use optimizes the activities of a financial institution, increasing efficiency, competitiveness and reducing the risks of fraud. A huge, but disparate customer data bank means limited use of artificial intelligence, however, combining technology and human experience to ensure customer safety today is the best solution.

New threats of technological and political nature come to the fore. New information technologies are formed on the basis of an assessment of these risks. They provide modern methods of identity verification in order to minimize suspicious transactions or open accounts. Information technology is aimed at analysing data from various sources, accelerating real-time security decisions, taking into account the requirements of regulators [3].

A special priority is the successful operation of the payment system. The growth of information and economic security for operators of payment systems, money transfers, payment infrastructure services and banks is provided by the Fid-Antifrod automated system. This system is a centralized database of cases and attempts to transfer money without the consent of the client, this system allows customers to assess the risks when making money transfers [11]. 


\section{Conclusions}

1. The financial sector is actively replacing traditional business models, technologies, products, new technologies (digital, telecommunications, biometric) [12]. These facts change not only the landscape, but also the structure of financial market players actively displacing traditional players and traditional business models.

2. Integration of new financial solutions based on the latest information technologies contributes to changing consumption patterns and reducing costs. The financial technology sector is becoming an independent sector of the economy.

3. Mobile and other portable devices make it possible to be present in cyberspace around the clock, these conditions require new ways to handle finances. These ways give rise to new risks, the need for changes in various spheres of activity of society.

4. New ways of dealing with finance require the creation of innovative information solutions involving the need for further political, legal, social, personnel policies at the national and international levels. Digitalization of the financial sector, based on a global rethinking of information solutions, is a key condition for the transition to sustainable development. The financial sector, being the blood system of the economy, is able to act as a driver of the sustainable development of the Russian economy

\section{References}

1. G.M. Kolpakova, The Value mechanism of the information society (2014)

2. Y. Evdokimova, O. Shinkareva, A. Bondarenko, Advances in Social Science, Education and Humanities Research, 240 (2018)

3. Information-age, Four ways banking security will change in 2020 (2020)

4. Bank of Russia, Fincert. Report of the monitoring center for computer attacks in the credit and financial sphere of the Information Security Department of the Bank of Russia 1.09.2018-31.08.2019 (2019)

5. TAdviser, TAdviser Review: IT in Banks 2019 (2019)

6. RAEX Analytics, Classification of banks by the level of use of artificial intelligence technologies (2020)

7. TAdviser, Russian banking informatization market (2019)

8. Association of Russian Banks, Internet Banking Rank 2020 (2020)

9. Markswebb, Internet Banking Rank 2020. How day-t-day tasks were evaluated in Internet banks (2020)

10. Bank of Russia, Main directions of development of information security of credit and financial sphere for the period of 2019-2021 (2019)

11. Bank of Russia, Annual report of the Bank of Russia for 2019 (2020)

12. Finam, Development of the fintech market in Russia-non-banks and startups (2019) 